\title{
原著
}

\section{メチシリン耐性黄色ブドウ球菌と感受性黄色 ブドウ球菌の細胞形態の比較}

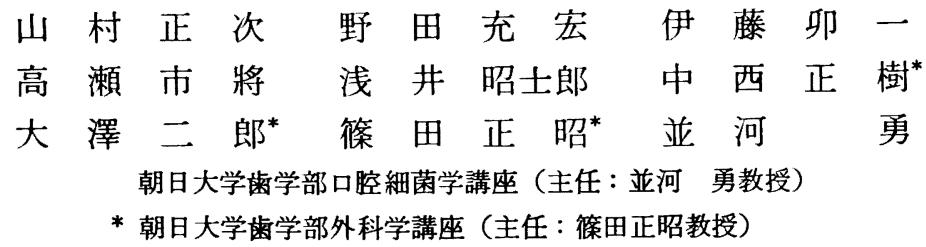

[受付：平成 4 年 7 月 20 日受付]

\section{A comparison of the cell morphology of methicillin-resistant}

\section{Staphylococcus aureus and -susceptible Staphylococcus aureus}

\author{
Masatsugu Yamamura, Mitsuhiro Noda, Uichi Ito, Ichio Takase, Shojiro Asai, \\ Masaki Nakanishi*, Jiro Ohsawa*, Masaaki Shinoda*, Isamu Namikawa
}

\author{
Department of Oral Microbiology \\ (Chief : Prof. Isamu Namikawa) \\ Department of Surgery \\ (Chief : Prof. Masaaki Shinoda) \\ School of Dentistry, Asahi University 1851 \\ Hozumi-cho, Motosu-gun, Gifu 501-02, Japan
}

[Accepted for publication : July 20, 1992]

Key word : MRSA/MSSA/Mutant strains/Cell wall/Coccal size

\begin{abstract}
It has been reported that methicillin-resistant strains of Staphylococcus aureus (MRSA) were slightly larger in coccal size than that of methicillin-susceptibe $S$. aureus (MSSA). However, the data in these reports were not exact because the observations by using microscope or transmission electron microscope on ultrathin sections were inadequate for measuring the coccal size.

The coccal size was examined by using a scanning electron microscope. In addition, the width of cell walls was examined by using a transmission electron microscope on the ultrathin sections. Both mutant MSSA strains lost methicillin-resistance from MRSA strain and MRSA strains selected as heterogeneous strains from MSSA were used for measuring the morphological size compared with clinical strains of MRSA and MSSA.

There were no significant differences in the coccal size and the width of the cell walls of MRSA, MSSA and mutant MRSA strains.

However, the width of the cell walls of the MRSA strain selected from MSSA was about $85 \%$ larger than that of the parent MRSA strain. The effect might be influenced by the used antibiotics. These results revealed that the differences between MRSA and MSSA strains were not significantly
\end{abstract}


in coccal size.

\section{緒言}

メチシリン（DMPPC）耐性 黄色ブドウ 球菌 (MRSA) は DMPPC 感受性黄色ブドウ球菌 (MSSA) と比べて, 菌体がやや大きく1)，その 増殖が遅い2)。また，細胞表層の構造の違い,3,4) などが報告されている。

しかし，菌体が確かにやや大きいかどうか，ま た，黄色ブドウ球菌のどの部分が大きいのかなど がいまだ，明らかにされていない。

本研究では, 両菌種間の細胞形態の相違を明確 にする目的で，まず，各種 MRSA および MSSA 株の菌体の直径を走査型電子顕微鏡で精密に測定 し比較した。また, ブドウ球菌の細胞膜は, 細胞 壁の内面と密着し, 電子密度の高い層を作ってい るため, その単位膜構造を見ることは難しい5)。 そのため, 細胞膜の厚さは測定が困難なので, 細 胞壁の厚さだけを透過型電子顕微鏡で測定した。

しかし, MRSA や MSSA に対するこれらの測 定結果が, DMPPC 耐性菌と感受性菌間の菌体直 径や細胞壁の厚さの相違ではなく, 単なる両菌種 の菌体固有の性質である可能性もある。そこで, in vitro で MRSA を培養して, その DMPPC 耐 性を脱落させた変異 MSSA 株を調製し, 親株と 比較検討した。また， MSSA をオキサシリン (MPIPC) 含有平板寒天培地で培養し, heterogeneity として混在すると考劣られている MSSA 菌集落の中の MRSA を選択し, 得られた MRSA 株についても検討した ${ }^{6)}$ 。

これらの方法を用いて, 両菌種間の菌体サイズ および細胞壁の厚さを精密に比較検討した。

\section{材料および方法}

\section{1. 菌株}

1) MRSA 株として名古屋大学医学部付属病 院検査部より分与された H103，H310，M145 お よびM118を用いた。

2) MSSA 株として Staphylococcus aureus IID
975 (Cowan I) および S. aureus ATCC 29213 を用いた。

3) メチシリン (DMPPC) 耐性を脱落させた MSSA 変異株は, MRSA の M145 を卵黄含有 Mannitol Salt (MS) 寒天培地で $32^{\circ} \mathrm{C}, 44$ 回44日間 培養し，MSSA に変異したものを MRSA のN24 株として使用した。また，別に MRSA の H103 株を $44^{\circ} \mathrm{C}, \mathrm{pH} 5.1$ の Trypticase Soy broth ( $\mathrm{T}$ $\mathrm{SB}, 4 \% \mathrm{NaCl}$ 含有）液体培地で35回35日間培養 し，耐性を脱落して MSSA となったものを N28 株として使用した。いずれる，最初にペニシリ ナーゼプラスミドを除去するため $44^{\circ} \mathrm{C}$ で一夜培 養した。処理菌がペニシリナーゼを産生している か否かはニトセフィン(BBL) で調べた7)。

4) MSSA 菌集落よりオキサシリン (MPIPC) で選択された MRSA 株は, MSSA の S. aureus ATCC 29213 をMRSA スクーリニング寒天培地 (MPIPC $6 \mu \mathrm{g} / \mathrm{ml}$ 含有, BBL) で 6 日間 $32^{\circ} \mathrm{C}$, 培養し，形成した単一集落より得，選択された MRSA そN39株とした。

\section{2. 培養方法}

TSB 寒天培地に, 各種菌株を接 種 し, 18時間 $37^{\circ} \mathrm{C}$ で培養した。次に, 培養した菌株を 3 回蒸 留水で洗浄し, 遠心し集菌したものを電子顕微鏡 標本作成試料とした。

\section{3. 供試抗生物質}

$\mathrm{DMPPC}(905 \mu \mathrm{g} / \mathrm{mg}$ 力価, シグマ), MPIPC $(892 \mu \mathrm{g} / \mathrm{mg}$, シグマ), ゲンタマイシン (GM, $618 \mu \mathrm{g} / \mathrm{mg}$, シェリング・プラウ), バンコマイシ ン ( $\mathrm{VCM}, 1,124 \mu \mathrm{g} / \mathrm{mg}$, 塩野義製薬), アンピ シリン (ABPC, $913 \mu \mathrm{g} / \mathrm{mg}$, 藤沢薬品工業) 扰よ びセファゾリン (CEZ, $936 \mu \mathrm{g} / \mathrm{mg}$, 藤沢薬品工 業）の原末を使用した。また，クロラムフェニコ 一ル (CP, 1, $000 \mu \mathrm{g}$, 三共) の市販品む使用 し た。

4. MRSA の判定

微量液体希釈法で最小発育阻止濃度 (MIC) を 測定し, 日本化学療法学会標準法に準じ, DMPP $\mathrm{C}$ の $\mathrm{MIC}$ 值 $12.5 \mu \mathrm{g} / \mathrm{ml}$ 以上のものを MRSA と判定した ${ }^{8)}$ 。すなわち, $128 \mu \mathrm{g} / \mathrm{m} l$ より 2 倍数 
Table 1 Antibiotic susceptibilities of MRSA and MSSA strains

\begin{tabular}{|c|c|c|c|c|c|c|}
\hline \multirow{3}{*}{ Strain } & \multicolumn{6}{|c|}{ Microdilution broth method } \\
\hline & DMPPC & MPIPC & GM & VCM & $\mathrm{ABPC}$ & CEZ \\
\hline & \multicolumn{6}{|c|}{$\operatorname{MIC}(\mu \mathrm{g} / \mathrm{m} l)$} \\
\hline \multicolumn{7}{|l|}{ Strains lost methicillin-resistance } \\
\hline N24 (from MRSA M145) & 1 & 0.125 & 128 & 1 & N.D.b) & 32 \\
\hline N28 (from MRSA H103) & 1 & 0.125 & 1 & 0.25 & 0.5 & 0.25 \\
\hline \multicolumn{7}{|l|}{ MRSA selected from MSSA } \\
\hline N39 (from $S$. aureus ATCC 29213) & 32 & 32 & 128 & 0.5 & 8 & 64 \\
\hline \multicolumn{7}{|l|}{ MSSA } \\
\hline S. aureus IID975 & 1 & 0.125 & 1 & 0.25 & 2 & 0.25 \\
\hline S. aureus ATCC29213 & 2 & 0.25 & 2 & 0.5 & 4 & 0.25 \\
\hline \multicolumn{7}{|l|}{ MRSA } \\
\hline M145 & 64 & 64 & 128 & 0.5 & 64 & 64 \\
\hline M118 & 64 & 64 & 128 & 0.5 & 128 & 64 \\
\hline H 103 & $>128$ & $>128$ & $>128$ & 8 & 128 & $>128$ \\
\hline H310 & $>128$ & $>128$ & 64 & 4 & 64 & $>128$ \\
\hline
\end{tabular}

a) DMPPC, methicillin ; MPIPC, oxacillin ; GM, gentamicin ; VCM, vancomycin ; ABPC, ampicillin ; CEZ, cefazolin

b) N.D. not done

系列希积の各供試抗生物質を含む TSB に, $37^{\circ} \mathrm{C}$ で静置培養した菌を最終濃度約 $10^{6} \mathrm{cells} / \mathrm{m} l$ に なるように調製して接種し， $32^{\circ} \mathrm{C} て ゙ 24$ 時間静置 培養後に, 肉眼的に発育が阻止された最終濃度を MIC 值とした。また, DMPPC および MPIPC の薬剤に対しては, 同様の操作で TBS の $\mathrm{NaCl}$ 濃度 $2 \%$ という培養条件下での MIC 值も測定し た。

処理株が MRSA および MSSA に確実にそれ ぞれ，選択されたかあるいは変異したか否かの判 定には 2 度, MIC 值を調へ，確認した。

5. 菌体直径の測定

各培養菌について, 通法に従い9，クルタール アルデヒドおよびオスミック酸でそれぞれ，2 時 間固定後, アルコール系による脱水を施し電顕標 本を作製した。その後, 酢酸イソアミルで置換し て, 臨界点乾燥した。さらに, ゴールドコーティ ングし, 走査電顕 (JSM-35, JEOL) にて標本観 察し，写真撮影したプリント上で菌体の直径をノ ギスで30個測定した。

\section{6. 細胞壁の厚さの測定}

前述のアルコール脱水後の試料の一部をエポキ
シ樹脂 (Epon 812) で包埋した。その後, ウルト ラミクロトーム（LKB 8800）で超薄切片を作成 し,さらに, 酶酸ウラニルとクェン酸鉛で二重染 色を施した。試料を透過電顕 (JEM 1200X, JE OL)で観察, 写真撮影したブリント上で細胞壁の 厚さを30個の細胞についてノギスで正確に測定し た。その際, 菌体の中心付近で切片が作られてい るものにするため, 測定するのは $0.5 \mu \mathrm{m}$ 以上の 直径を有する菌体に限定した。

\section{CP 処理菌株の調製}

抗生物質処理による細胞壁肥厚を調べるため に, S. aureus ATCC 29213 を, 18時間 TSB 寒天 培地で培養し, 集菌した。さらに, CP (最終濃 度 $20 \mu \mathrm{g} / \mathrm{ml}$ ) を含む $\mathrm{TSB}$ 液体培地で, $37^{\circ} \mathrm{C} 4$ 時間培養した ${ }^{10,11)}$ 。この培養菌について, 前述し た細胞壁の厚さの測定と同様な処理を施し, 電顕 標本を作成した。

\section{結 果}

1. 供試菌の薬剤感受性検査

各種菌株の薬剤感受性は Table 1 に示した。 


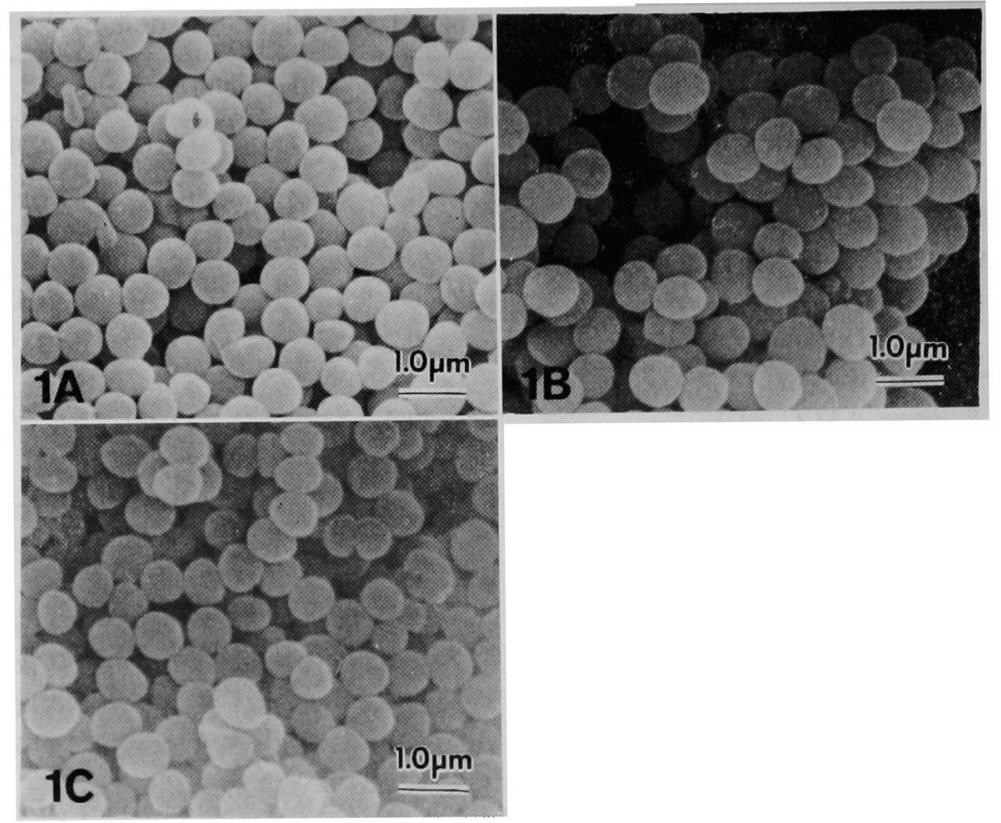

Fig. 1 Scanning electron micrographs of S. aureus ATCC 29213, MRSA selected from MSSA, and M118.

(A) MSSA $S$. aureus ATCC 29123, (B) MRSA N39 (from $S$. aureus ATCC 29213), (C) MRSA M118.

微量液体希釈法による薬剤感受性試験では, DM PPC 耐性を脱落させたN24 と N28株とも, MPI PC の MIC 値は0.125, また, DMPPC の MIC 值は 1 であり, 日本化学療法学会の判定基準 (D MPPC $12.5 \mu \mathrm{g} / \mathrm{ml}$ 以上を MRSA と判定) 以下 であったのでMSSA と判定した8)。また, 米国臨 床検査標準委員会 (NCCLS) の判定基準 (MPIPC $4 \mu \mathrm{g} / \mathrm{m} l$ 以上を MRSA と判定）にも準拠してい $た^{12)}$ 。

逆に, MSSA の S. aureus ATCC 29213 菌集落 から選択的に培養し, 得られた MRSA のN39株 では両薬剤とも MIC 值は32であったで, MRSA と判定した。また，供試臨床株 MSSA 2 株と MRSA 4 株はいずれる, 上記の判定基準に準拠 し，それぞれ，MRSA と MSSA であることが判 明した。MRSA のM145, H103とも GM, ABPC および CEZ のいずれの薬剤にる MIC 值 64 以上 の值を示した。一方, H103から DMPPC 耐性を 脱落させた N28株は, 親株の $\mathrm{H} 103$ が多剂耐性で あったにもかかわらず， 3 剂とも MIC 值 0.5 以
下の值であり多剤耐性も脱落し各種薬剂に感受性 を示した。しかし，M145からの耐性脱落 N24株 はそれらに対し, MIC 値 32 以上の值を示し, 多 剂耐性は脱落していなかった。

VCM に対しては, いずれの菌株も感受性菌で あった。

2. 菌体直径の測定

走查電顕写真 (Fig. 1) の判定により得られた測 定結果を Table 2 に示した。MSSA の S . aureus ATCC 29123 は 0.63土0.04 $\mu \mathrm{m}$ であり,この MSSA 菌集団から選択培養された MRSA のN39 株は $0.69 \pm 0.05 \mu \mathrm{m}$ を示した。さらに, MRSA の M118は 0.62士0.04 $\mu \mathrm{m}$ であった。

また，in vitro で耐性を脱落させ， MSSA とな った $\mathrm{N} 28$ 株は $0.73 \pm 0.04 \mu \mathrm{m}$ ，その親株 MRSA の $\mathrm{H} 103$ は $0.68 \pm 0.04 \mu \mathrm{m}$ を示した。

3. 細胞壁の厚さの測定

透過電顕写真上 (Fig. 2) から 細胞壁の厚さの サイズを測定し，得られた結果を Table 2 に示 した。供試した MRSA 株の細胞壁の厚さは26.5 
Table 2 Comparison of the diameter of cells and the width of cell walls in MRSA and MSSA strains.

\begin{tabular}{|c|c|c|c|}
\hline Strain & $\begin{array}{l}\text { Diameter of cells }{ }^{a)} \\
(\mu \mathrm{m})\end{array}$ & $\begin{array}{c}\text { Width of cell wal } \\
(\mathrm{nm})\end{array}$ & alls $s^{a}$ \\
\hline \multicolumn{4}{|l|}{ MRSA } \\
\hline $\mathbf{H} 310$ & N.D.b) & \multicolumn{2}{|l|}{$27.0 \pm 7.0$} \\
\hline H103 & $0.68 \pm 0.04$ & \multicolumn{2}{|l|}{ N.D. } \\
\hline M145 & N.D. & \multicolumn{2}{|l|}{$26.5 \pm 5.5$} \\
\hline M118 & $0.62 \pm 0.04$ & \multicolumn{2}{|l|}{$32.1 \pm 8.2$} \\
\hline \multicolumn{4}{|l|}{ MSSA } \\
\hline S. aureus ATCC 29213 & $0.63 \pm 0.04$ & \multicolumn{2}{|l|}{$21.4 \pm 3.0-$} \\
\hline S. aureus 11D975 & N.D. & $27.6 \pm 5.9$ & c) \\
\hline \multicolumn{4}{|l|}{ MRSA selected from MSSA } \\
\hline N39 (from S. aureus 29213) & $0.69 \pm 0.05$ & \multicolumn{2}{|l|}{ 39. $7 \pm 12.1-$} \\
\hline \multicolumn{4}{|l|}{ Strains lost methicillin-resistance } \\
\hline N28 (from MRSA $\mathrm{H} 103$ ) & $0.73 \pm 0.04$ & \multicolumn{2}{|l|}{$32.7 \pm 6.8-$} \\
\hline N24 (from MRSA M145) & N.D. & \multicolumn{2}{|l|}{$28.0 \pm 4.7$} \\
\hline \multicolumn{2}{|l|}{ Chloramphenicol-treated strains } & \multicolumn{2}{|r|}{ d) } \\
\hline S. aureus ATCC 29213 & N.D. & \multicolumn{2}{|l|}{$28.4 \pm 5.7$} \\
\hline N39 (from $S$. aureus ATCC 29213) & N.D. & \multicolumn{2}{|l|}{$50.7 \pm 7.8-$} \\
\hline M118 & N.D. & \multicolumn{2}{|l|}{$30.5 \pm 3.5$} \\
\hline M145 & N.D. & \multicolumn{2}{|l|}{$35.0 \pm 5.3$} \\
\hline $\begin{array}{l}\text { a) Values are expressed as mean } \pm \text { S.D } \\
\text { b) N.D. not done. } \\
\text { c) } p<0.05 \text { by } t \text { test. } \\
\text { d) } p<0.05 \text { by } t \text { test. }\end{array}$ & $\mathrm{N}=30)$ & & \\
\hline
\end{tabular}

$\pm 5.5 \mathrm{~nm}$ から $32.1 \pm 8.2 \mathrm{~nm}$ の範囲にあった。

一方, MSSA 株として, S. aureus ATCC 29213 は21.4土3.0 nm および $S$. aureus IID 975は27.6 $\pm 5.9 \mathrm{~nm}$ を示した。in vitro 調製菌株では, MS SA の $S$. aureus ATCC 29123 より選択培養され た N39 株は $39.7 \pm 12.1 \mathrm{~nm}$ であった。本菌は親 株の MSSA S. aureus ATCC 29213 のその厚さと 比較して有意 $(p<0.05)$ の差があり, 約 $85 \%$ 肥 厚した。また，N39 株を CP 処理すると，50.7 $\pm 7.8 \mathrm{~nm}$ を示し, さらに約 $28 \%(p<0.05)$ 肥

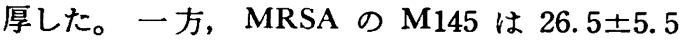
$\mathrm{nm}, \mathrm{CP}$ 処理で $35.0 \pm 5.3 \mathrm{~nm}$ を示した。また, MRSA の M118は, 32.1土8.2nm のサイズが CP 処理で 30.5土3.5 nm となり, 有意の差はな かった。S.aureus ATCC 29213 は $21.4 \pm 3.0 \mathrm{~nm}$ が CP 処理で 28.4士5.7 nm となった。CP 処 理で, さらに, 細胞壁の肥厚現象が進行したこと が認められた。

\section{考察}

従来, MRSA MSSA と比較して細胞形態が やや大きいと報告されてきた。しかし，以前のこ れらの直径サイズに関する報告は, 光顕写真によ る測定のため細胞壁境界が明瞭に観察できないの で精密に測定できなかった ${ }^{13,14)}$ 。また，超薄切片 を用いた透過電顕写真による菌体直径サイズの測 定の報告では, 細胞が菌体中心付近で切片がすべ て作られているわけではないので, 菌体サイズが 実際よりす小さいるのも混入し，その際のデータ は正確ではなかった ${ }^{15)}$ 。しかし，本実験で用いた 走査電顕写真による測定では, 菌体直径について は光顕観察による場合より, 菌体の外壁が明瞭で あるため, 正確に測定できた。従来，MRSA と MSSA の細胞壁の厚さのサイズについて 報告は されていなかったが本研究で初めて精密に比較検 


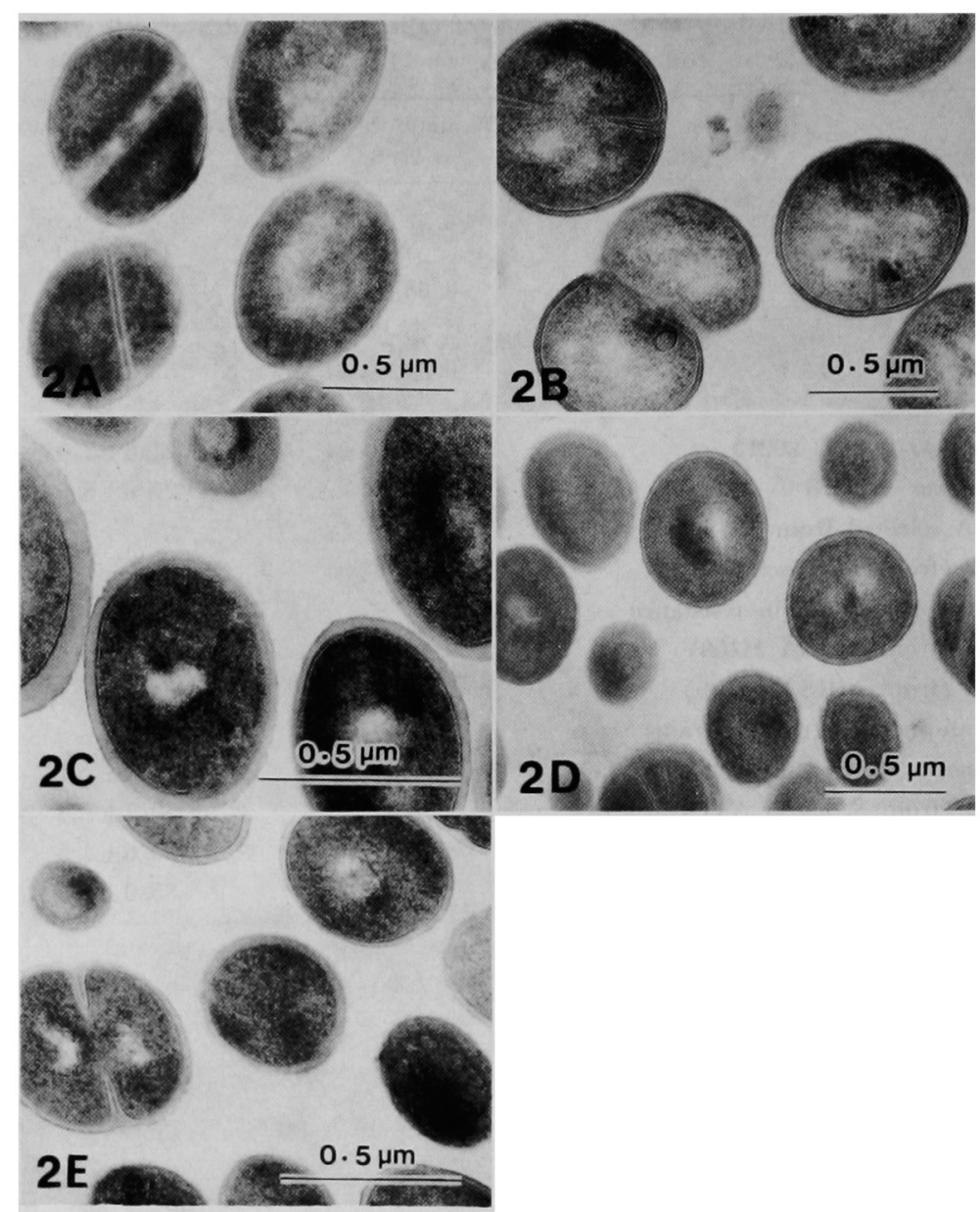

Fig. 2 Transmission electron micrographs of MSSA, MRSA selected from MSSA, and chloramphenicol-treated MRSA.
(A) MSSA $S$. aureus ATCC 29213
(B) N39 (from $S$. aureus ATCC 29213)
(C) MRSA N39 treated with chloramphenicol $(20 \mu \mathrm{g} / \mathrm{ml})$ f(r 4 $\mathrm{hr}$ of incubationn.
(D) MRSA M145
(E) MRSA M145 treated with chloramphenicol $(20 \mu \mathrm{g} / \mathrm{m} l)$ for $4 \mathrm{hr}$ of incubation.

討した。また，臨床分離株の MRSA と基準株の MSSA 株で比較した場合には，これらの測定結果 が菌株の単なる固有の性質としてのサイズである 可能性もある16,17)。そこで, in vitro で MRSA 拉 よび MSSA をそれぞれ選択培養打よび変異させ た菌株を比較検討することで, DMPPC 耐性菌と 感受性菌株間でその直径㧍よび細胞壁の厚さのサ イズに本質的な差があるか否かを検討した。
MRSA 株のH103 およびM118 MSSA 株の S. aureus ATCC 29213 をその菌体サイズで比較 してみると有意の差は認められなかった。また， MSSA の $S$. aureus ATCC 29213 から MRSA を 選択培養した株と，逆に，MRSA のH103株を耐 性を脱落させた MSSA 変異株でも両者に有意の 差はなかった。

臨床分離株間だけでなく, in vitro で変異およ 
び選択させた菌株間でもこれらのサイズに有意の 差がないことが示されたことから，MRSA とM SSA の両菌種間では，菌体直径に有意の差がな いことが示唆された。

細胞壁の厚さのサイズでは, 臨床分離侏の MR SA と MSSA 菌種間扐よび耐性脱落株の MSSA 変異株では有意の差はなく, 細胞壁の肥厚現象は 認められなかった。

しかし, S. aureus ATCC 29213 は in vitro で 得られた選択株の MRSA のN39株と比べて有意 の差 $(p<0.05)$ があった。そのため, 細胞壁の 厚さが親株の MSSA と比較して, 約 $85 \%$ 有意に 肥厚していることが認められた。

この現象は, 变異株では抗生物質に実験終了ま で, 接触していたため, その抗生物質によって細 胞壁の肥厚現象が起きたと考えられる。この観察 は使用した薬剤の作用点は異なるが, $\mathrm{CP}$ 処理に よる $S$. aureus の細胞壁肥厚に関する以前の報告 と関連しているかるしれない18-20)。

$\mathrm{CP}$ 処理したN39株は親株と比べて, 約 $28 \%$ 増 大 $(p<0.05)$ したので, 細胞壁の肥厚現象は本 実験でも認められた。しかし，臨床分離 MSSA 株では, 過去に, 抗生物質との接触があったた め, 細胞壁の肥厚が観察されなかったと考えられ た。

選択された N39株は, 親株 (MSSA S. aureus ATCC 29213）と比べて, 菌体直径は有意の差が ないのに，細胞壁に約 $85 \%$ の肥厚が認められた。 しかし, この肥厚現象はこれらの菌株の菌体直径 サイズの差として示されなかった。この理由は, 菌体直径のサイズ測定には $\mu \mathrm{m}$ の単位, 細胞壁の 厚さの剆定には $\mathrm{nm}$ を用い，それぞれ透過および 走査電顥写真上で判定したので細胞壁の厚さの単 位は微小になり，菌体直径サイズの測定の際には 誤差範囲となったためである。

In vitro で MSSA 菌集落から選択された N39 株の調製は, 薬剤感受性試験の MIC 值測定で日 本化学療法学会の判定基準値（DMPPC $12.5 \mu \mathrm{g}$ / $\mathrm{m} l$ 以上で MRSA と判定), また, NCCLS の判 定基準值 (MPIPC $4 \mu \mathrm{g} / \mathrm{m} l$ 以上で MRSA と判 定）を示し，明確にMRSA と判定できた。また， GM および CEZ にも耐性を示し, 多剂耐性菌
に変異していた。

一方, 供試 MRSA 株の耐性を脱落させた株の 2 菌株N24 と 28 は，MSA と判定できたが，N 28株は多剂耐性を同時に脱落し，感受性菌となっ ていた。しかし，N24株は多放耐性を脱落してい なかった。この現象は調製方法の相違によると考 えられる。すなわち，N28株を調製した液体培地 （pH 5.6）の方が寒天培地（pH 7.2）よりる多剤 耐性の脱落に適していたと思われる。

本実験では供試菌について mec A 遺伝子の検 出は行っていないが, 日本化学療法学会の判定基 準で判定された MRSA は，いままで調べられた 菌株についてすべて mec A 遺层子を有していた と報告されている16)。しかし，漂準法で MSSA と判定された菌株の中に, mec $\mathrm{A}$ 遺云子を持つも のがあることが判明している21)。加えて, MRSA は mec A 遺层子が外来より MSSA に取り込ま れて DMPPC 耐性株になるのであって, MSSA に mec $\mathrm{A}$ 遺云子が薬剤処理で突然变異的に誘導 されるのではないと考えられている22)。

しかし, 本研究に用いられた供試菌および in vitro 調製菌株の酎性判定は，すべて日本化学療法 学会の判定基準の MIC 值を指標にしているの で, 本実験結果は DMPPC 耐性現象と菌体およ び細胞壁の厚さのサイズの関係を示㖫していると 考えられる。

\section{結論}

MRSA，MSSA，MRSA より耐性を脱落させた 変異 MSSA 株および MSSA 菌集落から選択し た MRSA 株を用いて, 菌体の直径および細胞壁 の厚さのサイズを, それぞれ，走査電顕および透 過電顕で精密に測定し，次の結果を得た。

1. 菌体の直径は, MRSA のH103株は0.68土 $0.04 \mu \mathrm{m}, \mathrm{M} 118$ 株は $0.62 \pm 0.04 \mu \mathrm{m}$ であった。 一方, MSSA の S. aureus ATCC 29213 株は 0.63 $\pm 0.04 \mu \mathrm{m}$ であった。選択培養させた MRSA の N39 株では, その菌体直径は $0.69 \pm 0.05 \mu \mathrm{m}$, MRSA のH103侏を MSSA に変異させたN28株

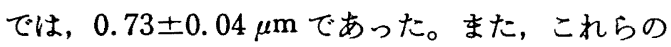
結果は MRSA と MSA 株間で統計的な有意差 
を示さなかった。

2. 菌体細胞壁の厚さは, MRSA の H310株, $27.0 \pm 7.0 \mathrm{~nm}, \mathrm{M} 145$ 株, $26.5 \pm 5.5 \mathrm{~nm}, \mathrm{M} 118$ 株, $32.1 \pm 8.2 \mathrm{~nm}$ であった。一方, MSSA の $S$. aureus ATCC 29213株 $21.4 \pm 3.0 \mathrm{~nm}, S$. aureus IID 975 株 $27.5 \pm 5.9 \mathrm{~nm}$ であった。また，N39 株では $39.7 \pm 12.1 \mathrm{~nm}$ であった。N39株の細胞壁はその 親株と比べて約 $85 \%(p<0.05)$ 肥厚した。

3. PC $(20 \mu \mathrm{g} / \mathrm{m} l)$ で 4 時間処理した N39 株 は，細胞壁の厚さが約 $28 \%$ 肥厚した。

以上の結果により, MRSA は MSSA と比べ て，その菌体直径がやや大きいといらことはなか った。また，in vitro 調製の変異株および選択株 でも直径に差がなかったことから，単なる菌株固
有の性質というより，MRSA と MSSA の菌株間 で菌体直径に差がないことを示唆した。

細胞壁の厚さは, 臨床分離株で有意差はなかっ たが，MSSA 菌集落から MRSA を選択培養した 菌株では, 前者の分離株とは異なって標本調製直 前まで，抗生物質に接触していたので，その作用 のために，肥厚したと考えられる。これらの現象 は作用機序は異なるが，タンパク質合成阻害剤で ある CP で菌株を処理すると細胞壁肥厚現象が 起きることが報告されていること，また，本実験 でも同様の結果が得られたことから，このような 抗生物質による肥厚現象を支持していると思われ る。

抄録：MRSA は，その細胞形態が MSSA と比較して，やや大きいと以前から報告されている。本研究 では，MRSA と MSSA の相違を明確にする目的で従来報告されていない精密な測定方法を用い，菌体の 直径扣よび細胞壁の厚さのサイズを，それぞれ，走査電顕扣よび透過電顕で精密に測定した。これらの現象 をさらに, MRSA, MSSA, MRSA ょり耐性を脱落させた変異株扣よび MSSA 菌集落から選択的に MRSA を分離した菌株を用いて比較検討した。その結果，MRSA 株と MSSA 株間ではその菌体直径および細胞 壁の厚さのサイズに差がないことが示唆された。また，これらの現象はそれぞれの変異株および選択株でも 変化がなかった。親株とその変異株でも同様に有意差がなかったことは，単に供試した菌株の性質ではな く, MRSA 株と MSSA 株でこれらのサイズに差がないことを示している。しかし，選択菌株では，その 細胞壁の厚さが約 $85 \%$ 肥厚した。これらの現象は，臨床分離侏と異なって培養直前まで抗生物質に接してい たために，肥厚現象が起こったと推定された。

MRSA の菌株を分与して頂きました，名古屋大学医学部の太田美智男助教授および名古屋大学医学部付 属病院検査部の一山智先生に感謝致します。

電子顕微鏡の観察に際し，技術的な指導を受けた朝日大学歯学部中央研究施設主任の森 春義および梅原 則明氏に感謝致します。

本研究の一部は, 平成 3 年度東海乳酸菌研究会（ヤクルト主催）(名古屋，1992年）扣よび第 65 回日本細 菌学会総会（盛岡, 1992年）に打いて発表した。

また，本研究の一部は，昭和63年度宮田研究奖励金（A）拈よび平成 3 年度ヤクルト㧣の研究助成金で行 った。

\section{文献}

1) Sabath, L.D. and Wallace, S.J. : Factors influencing methicillin resistance in staphylococci. Ann. N.Y. Acad. Sci. 182:258-266, 1971.

2) Sutherland, R. and Rolinson, G.N. : Characteristics of methicillin-resistant staphylococci. J. Bacteriol. 87 : 887-899, 1964.

3) Wilkinson, B.J., Dorian, K.J. and Sabath, L.D. : Cell wall composition and associated properties of methciillin-resistant Staphylococci aureus strains. J. Bacteriol. 136 : 976-982, 1978.

4) Sabath, L.D., Leaf, C.D., Gerstein, D.A. and Finland, M. : Altered cell walls of Staphylococcus aureus resistant to methicillin. Nature $225: 1074,1970$.

5) Suganuma, A. : Fine structure of staphylococci ; Electron Microscopy. in The staphylococi, Ed. J.O. Cohen, Wiley-Interscience, pp 2140, N.Y., 1972. 
6）横田 健：MRSA の発生機序とその毒性 臨 床消化器内科 $6: 615-627,1991$.

7) O'Callaghan, C.H., Morris, A., Kirby, S.M. and Shingler, A.H. : Novel method for detection of $\beta$-lactamase by using a chromogenic cephalosporin substrate. Antimicrob. Agents Chemother. 1 : 283-288, 1972.

8）日本化学療法学会 抗菌薬感受性測定検討委員 会報告：媺量液体希釈による MIC 測定（微量 液体希积法) Chemotherapy $38: 102-105$, 1990.

9）浅井昭士郎，中村義則，中谷至宏，佐藤 勝， 並河 勇：口腔トリコモナスの生物学的性状一 異物貪食作用，低級脂肪酸産生および EB ウイ ルス抗原誘導能一. 歯基礎誌 33:354-364, 1991.

10) Giesbrecht, P., Wecke, J. and Reinicke, B. : On the morphogenesis of the cell wall of staphylococci. Int. Rev. Cytol. 44 : 225-318, 1976.

11) Redai, I., Sebessy-Gonczy and Vaczi, L. : Effect of chloramphenicol on phospholipid synthesis in sensitive Staphylococcus aureus strains. Acta. microbiol. Acd. Sci. Hung, 19 : 187-193, 1972.

12) National Committee for Clinical Laboratory Standards, 1990. Methods for dilution antimicrobial susceptibility tests for bacteria that grow aerobically, 2 nd ed. Approved Standard. NCCLS document M7-A2. National Committee for clinical Laboratory Standard. Villanova, $\mathrm{Pa}$.

13) Bulger, R.J. and Bulger, R.E. : Ultrastructure of small colony variants of a methicillinresistant Staphylococcus aureus. J. Bacteriol. 94 : 1244-1246, 1967.
14) Bulger, R.J., Collman, M. and Feigl, P. : A comparison of the ultrastructure of the smallcolony variant and the parent strain of methicillin-resistant Staphylococcus aureus. J. Infect. Dis., 125 : 1-4, 1972.

15) Barber, M. : Naturally occuring methicillinresistant stphyloocci. J. gen. Microbiol. 35 : 183-190, 1964.

16）菅野治重：mec A遗层子の構造と機能. 日本臨 床 50 : 1016-1019, 1992.

17) Hiramatsu, K., Kihara, H. and Yokota, T. : Analysis of borderline-resistant strains of methicillin-resistant Staphylococcus aureus using polymerase chain reaction. Microbiol. Immunol. 36 : 445-453, 1992.

18) Lorian, V., Atkinson, B., Waluschka, A. and Kim, Y. : Ultrastructure, in vitro and in vivo, of staphylococci exposed to antibiotics. Cur. Microbiol. 7 : 301-304, 1982.

19) Wale, L.J., Shelton, A.P. and Greenwood, D. : Scanning electron-microscopy of Staphylococcus aureus and Enterococcus faecalis exposed to daptomycin. J. Med. Microbiol. 30 : 45-49, 1989.

20) Chambers, H.F., Hartman, B.J., and Tomasz, A. : Increased amounts of a novel penicillinbinding protein in a strain of methicillinresistant Staphylococcus aureus exposed to nafcillin. J. Clin. Invest. 76 : 325-331, 1985.

21）庄司 聡, 菊池宏明, 渡辺 影, 本宮雅吉: M RSA の $\beta$-lactamase 産生能一MRSA $<\mathrm{MS}$ SA の比較一. 日本臨床 50 : 1049-1053, 1992.

22）平松啓一：MRSA の分子遺云学. 日本臨床 50 : 938-944, 1992. 